\title{
Luminescent $\mathrm{ZnO}-\mathrm{Al}_{2} \mathrm{O}_{3}-\mathrm{SiO}_{2}$ glasses and glass ceramics
}

\author{
D. Ehrt* , H. T. Vu, A. Herrmann and G. Völksch \\ Otto-Schott-Institut, University Jena, Fraunhoferstr. 6, D-07743 Jena, Germany \\ e-mail: doris.ehrt@uni-jena.de
}

Keywords: zinc silicate, glasses, ceramics, photoluminescence, samarium, optical and thermal properties

Abstract. Glasses in the composition range in mol\% 35-50 $\mathrm{ZnO}-10-15 \mathrm{Al}_{2} \mathrm{O}_{3}-40-55 \mathrm{SiO}_{2}$ were prepared, undoped and doped with $1 \times 10^{19}$ and $1 \times 10^{20} \mathrm{Sm}^{3+}$ per $\mathrm{cm}^{3}$ glass as luminescent species for the visible region, especially for blue and red emission.

Phase separation occurs in glass samples with high $\mathrm{SiO}_{2}$ content. $\mathrm{SiO}_{2}$-rich droplets in a $\mathrm{Zn}^{2+}-\mathrm{Al}^{3+}$ enriched matrix were formed. $\mathrm{Sm}^{3+}$ ions prefer the $\mathrm{Zn}^{2+}-\mathrm{Al}^{3+}$-rich glass matrix.

By thermal treatment glass samples were transformed into glass ceramics with the main crystal phases: $\mathrm{Zn}_{2} \mathrm{SiO}_{4}$ (willemite), $\mathrm{ZnAl}_{2} \mathrm{O}_{4}$ (gahnite) and $\mathrm{SiO}_{2}$-mixed crystals. XRD, SEM and TEM measurements were carried out. The luminescent $\mathrm{Sm}^{3+}$ ions are concentrated in the glass matrix.

Photoluminescence excitation and emission spectra were recorded in the UV-VIS-region and the time resolved emission behavior was measured by excitation with a $\mathrm{N}_{2}$-laser at $337 \mathrm{~nm}$.

The glasses and glass ceramics have interesting chemical and physical properties, high $\mathrm{T}_{\mathrm{g}}$ around $700^{\circ} \mathrm{C}$, low coefficient of thermal expansion $\sim 4 \mathrm{ppm} / \mathrm{K}$, and high chemical stability.

\section{Introduction}

Glasses and ceramics find various applications in different technical and optical fields because of their wide spread of physical-chemical properties. On the basis of the system $\mathrm{ZnO}-\mathrm{Al}_{2} \mathrm{O}_{3}-\mathrm{SiO}_{2}$ glasses with high $\mathrm{T}_{\mathrm{g}}$ around $700^{\circ} \mathrm{C}$, low thermal expansion coefficient around $4 \mathrm{ppm} / \mathrm{K}$, and high chemical stability can be prepared. Glass-ceramics with the crystal phases $\mathrm{Zn}_{2} \mathrm{SiO}_{4}$ (willemite), $\mathrm{ZnAl}_{2} \mathrm{O}_{4}$ (gahnite) and high quartz can be obtained by thermal treatment [1-3].

Crystalline $\mathrm{Zn}_{2} \mathrm{SiO}_{4}$ doped with small amounts of $\mathrm{Mn}^{2+}$ is a well known green-emitting lamp and cathode-ray phosphor [4].The use of fluorescence measurement techniques is expanding rapidly.

In this work, the luminescent behavior of $\mathrm{Sm}^{3+}$, with $4 \mathrm{f}^{5}$ electronic configuration which provides strong emission in the visible range (orange-red), has been studied in glasses and glass ceramics with high $\mathrm{ZnO}$ content by different methods.

\section{Experimental}

Glasses in the composition range in mol\% 35-50 $\mathrm{ZnO}-10-15 \mathrm{Al}_{2} \mathrm{O}_{3}-40-55 \mathrm{SiO}_{2}$ undoped and doped with $1 \times 10^{19}$ and $1 \times 10^{20} \mathrm{Sm}^{3+}$ per $\mathrm{cm}^{3}(\sim 0.1$ and $1.0 \mathrm{wt} \%)$ were prepared. Mixtures $(200 \mathrm{~g})$ of high purity raw materials $(\mathrm{Fe}<1 \mathrm{ppm})$ were melted in Pt crucibles at $1550^{\circ} \mathrm{C}$ for $2 \mathrm{~h}$. The melts were fritted in water and remelted in Pt crucible for $2 \mathrm{~h}$. Than the melts were poured in moulds or quenched on copper plates to avoid phase separation. After annealing from $750^{\circ} \mathrm{C}$ with $3-5 \mathrm{~K} / \mathrm{min}$ the glasses were cut, ground and polished to produce samples for different measurements. The optical absorption spectra $(190-3200 \mathrm{~nm})$ were recorded with sample thicknesses of 2 and $10 \mathrm{~mm}$ with an error $<1 \%$. Fluorescence excitation and emission spectra were recorded (200-900 nm) with an intensity error $<5 \%$. The fluorescence decay curves were measured with a special experimental setup after excitation at $337 \mathrm{~nm}$ with a short $\mathrm{N}_{2}$-laser pulse [5]. The refractive indices were measured with an error $\Delta \mathrm{n} \pm 2 \times 10^{-5}$. The density of the glass was determined using Archimedes' principle, error \pm 0.002 . DTA, dilatometer and viscometer measurements were carried out to obtain 
values for the thermal properties. X-ray diffraction (XRD), and electron microscopy (SEM, TEM, with EDX and WDX) measurements were used to characterize the crystallization behavior.

\section{Results and discussion}

Normally glasses and glass ceramics were investigated with high $\mathrm{SiO}_{2}$, higher $\mathrm{Al}_{2} \mathrm{O}_{3}$, lower $\mathrm{ZnO}$ content, and with addition of other components, especially nucleating agents, like $\mathrm{TiO}_{2}$ or $\mathrm{ZrO}_{2}$, e.g. to get transparent glass ceramics based on spinel composition with gahnite $\left(\mathrm{ZnAl}_{2} \mathrm{O}_{4}\right)$ as main crystalline phase $[2,3]$. In this work the main crystal phase should be willemite $\left(\mathrm{Zn}_{2} \mathrm{SiO}_{4}\right)$. Surprisingly it was possible to obtain bulk glasses up to very high $\mathrm{ZnO}$ content, $50 \mathrm{~mol} \%$, and low $\mathrm{SiO}_{2}$ content, $40 \mathrm{~mol} \%$. The phase diagram of the binary $\mathrm{ZnO}-\mathrm{SiO}_{2}$ system shows stable phase separation in the melt, $\mathrm{T}>1700^{\circ} \mathrm{C}$, up to $\sim 40 \mathrm{~mol} \% \mathrm{ZnO}$, and an eutectic composition, $50 \mathrm{~mol} \%$ $\mathrm{ZnO}-50 \mathrm{SiO}_{2}$, with $\mathrm{T}_{1} \sim 1430^{\circ} \mathrm{C}$ [6]. Glasses ZAS1 and ZAS4 provided phase separation by normal cooling (Fig. 6a ) and were homogenous by quenching. All other compositions (Table 1) yielded homogenous glasses with high $\mathrm{T}_{\mathrm{g}} \sim 700^{\circ} \mathrm{C}$ and low thermal expansion coefficients, $\sim 4$ $\mathrm{ppm} / \mathrm{K}$. Glass ceramics with lower TEC values (nearly 0 !) were also obtained in special cases.

The refractive indices increase with increasing $\mathrm{ZnO}$ content from 1.61 to 1.67 , and decrease with increasing $\mathrm{Al}_{2} \mathrm{O}_{3}$ content. The changes in the Abbe number are only small.

Table 1: Composition (in mol\%) and properties measured on the undoped glasses

\begin{tabular}{|c|c|c|c|c|c|c|c|c|}
\hline Glass & $\mathrm{ZnO}$ & $\mathrm{Al}_{2} \mathrm{O}_{3}$ & $\mathrm{SiO}_{2}$ & $\begin{array}{c}\mathrm{T}_{\mathrm{g}} \pm 5 \\
{\left[{ }^{\circ} \mathrm{C}\right]}\end{array}$ & $\begin{array}{c}\text { density } \\
{\left[\mathrm{g} / \mathrm{cm}^{3}\right]}\end{array}$ & $\begin{array}{c}\text { refractive } \\
\text { index }(546 \mathrm{~nm})\end{array}$ & $\begin{array}{c}\text { Abbe } \\
\text { number } \pm 1\end{array}$ & $\begin{array}{c}\mathrm{TEC} \pm 0.1 \\
{[\mathrm{ppm} / \mathrm{K}]}\end{array}$ \\
\hline ZAS1 & 35 & 10 & 55 & 705 & 3.24 & 1.6135 & 51 & 3.6 \\
\hline ZAS4 & 40 & 10 & 50 & 700 & 3.42 & 1.6331 & 50 & 3.9 \\
\hline ZAS5A & 45 & 10 & 45 & 690 & 3.53 & 1.6630 & 47 & 3.8 \\
\hline ZAS5B & 42.5 & 12.5 & 45 & 700 & 3.47 & 1.6426 & 49 & 4.0 \\
\hline ZAS5C & 40 & 15 & 45 & 700 & 3.41 & 1.6367 & 50 & 3.8 \\
\hline ZAS6 & 50 & 10 & 40 & 690 & 3.64 & 1.6681 & 47 & 3.9 \\
\hline
\end{tabular}

The homogenous glass samples have high UV transmission with an UV-edge around $230 \mathrm{~nm}$. The $\mathrm{Sm}^{3+}$-doping causes weak narrow absorption bands due to f-f-electronic transitions. The strongest band has the maximum at $402 \mathrm{~nm}$ (Fig. 1). The optical absorption spectra correlate with the fluorescence excitation spectra (Fig. 2). The glass samples are colorless or weak yellow in the case of $10^{20} \mathrm{Sm}^{3+} / \mathrm{cm}^{3}$ doping.

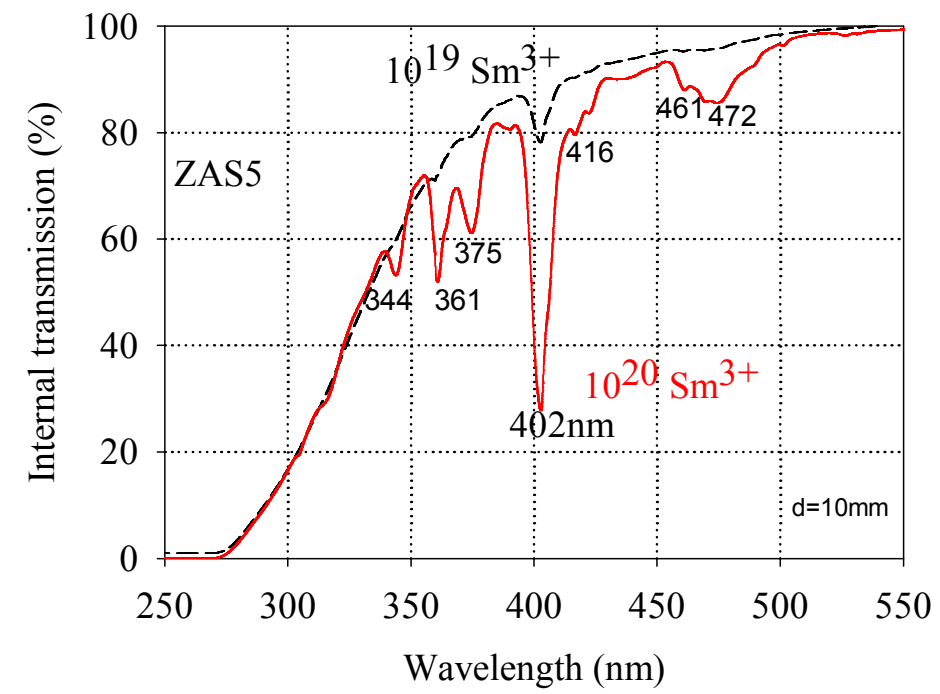

Fig. 1: Optical transmission spectra in the UV-Vis region demonstrated at glass samples ZAS5 doped with $10^{19}$ and $10^{20}$ $\mathrm{Sm}^{3+}$ per $\mathrm{cm}^{3}\left(\sim 0.1\right.$ and $\left.1.0 \mathrm{wt} \% \mathrm{Sm}_{2} \mathrm{O}_{3}\right)$ with sample thickness $10 \mathrm{~mm}$.

The optical absorption intensity increases linear with the doped $\mathrm{Sm}^{3+}$ concentration, but the fluorescence intensity shows concentration quenching effect at $10^{20}$ $\mathrm{Sm}^{3+}$ per $\mathrm{cm}^{3}$. Fluorescence emission bands at $\sim 560,600$ and $650 \mathrm{~nm}$ were measured after excitation at $\sim 400 \mathrm{~nm}$. Lifetimes with $\tau_{\mathrm{e}} \sim 2.2 \mathrm{~ms}$ for $10^{19}$

$\mathrm{Sm}^{3+} / \mathrm{cm}^{3}$ and $1.8 \mathrm{~ms}$ for $10^{20} \mathrm{Sm}^{3+} / \mathrm{cm}^{3}$ were determined (Fig. 4). 


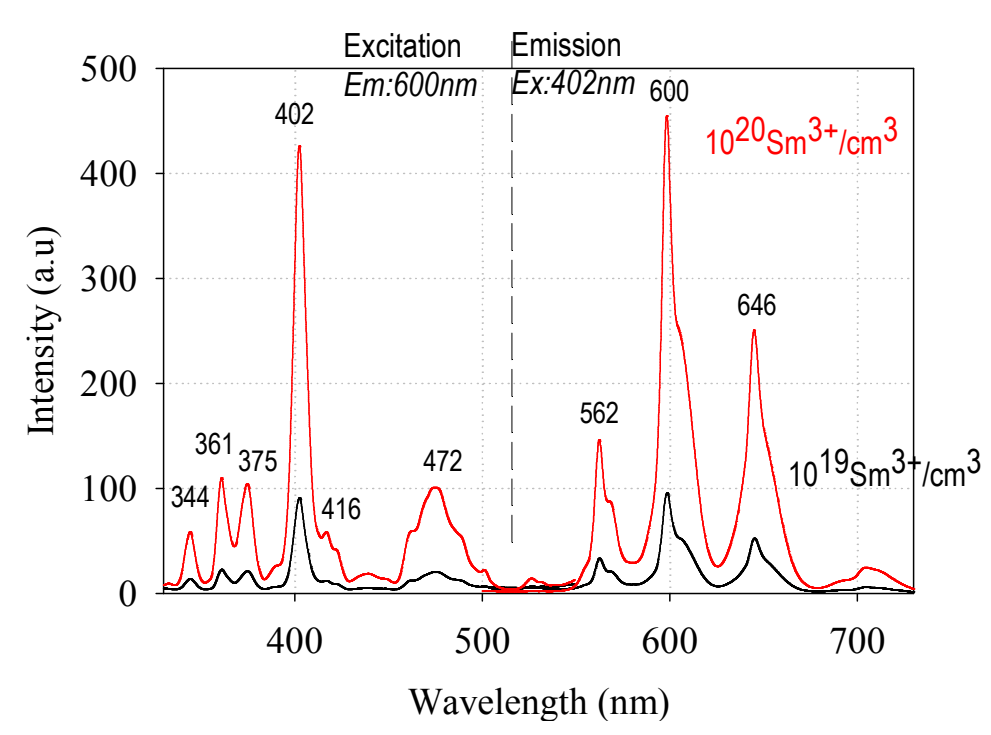

Fig. 2: Fluorescence excitation and emission spectra typical for all glass samples doped with $10^{19}$ and $10^{20}$ $\mathrm{Sm}^{3+} / \mathrm{cm}^{3}$ with lifetimes $\tau_{\mathrm{e}} \sim 2.2$ and 1.8 ms, demonstrated with ZAS5 samples. Effect of concentration quenching at higher $\mathrm{Sm}^{3+}$ doping can be recognized.

Very interesting is the strong increase of fluorescence intensity which could be obtained by special thermal treatment and lead to phase separation or a translucent glass ceramic.

The fluorescence intensity of the phase separated glasses and the translucent glass ceramic were much higher due to accumulation of the $\mathrm{Sm}^{3+}$ in the glass matrix and amplification by scattering effects of small $\mathrm{SiO}_{2}$-rich droplets or small crystals (Fig. 3). The translucent glass ceramic was obtained by two step thermal treatment, at $750^{\circ} \mathrm{C}$ for 10 hours and at $850^{\circ} \mathrm{C}$ for 5 hours.

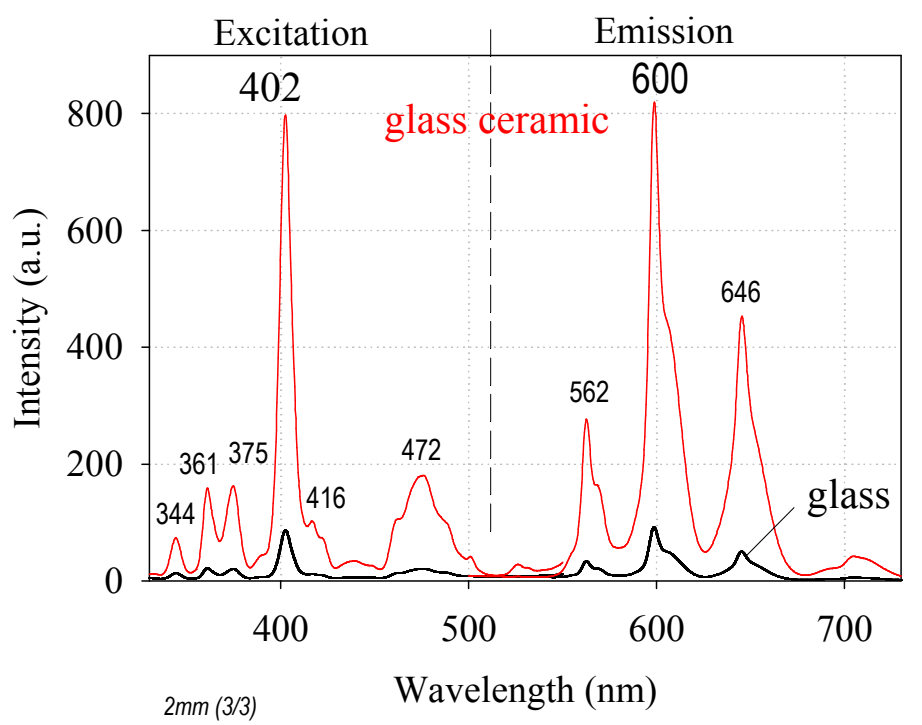

Fig.3: Fluorescence excitation and emission spectra of glass and translucent glass ceramic sample with the same composition, ZAS5 $/ 10^{19} \mathrm{Sm}^{3+} / \mathrm{cm}^{3}$.

It was possible, to get with lower $\mathrm{Sm}^{3+}$ doping $\left(10^{19} / \mathrm{cm}^{3}\right)$ a much higher fluorescence intensity than with higher $\mathrm{Sm}^{3+}$-doping $\left(10^{20} / \mathrm{cm}^{3}\right)$.

The effect of fluorescence amplification by translucent crystallization was much lower at higher $\mathrm{Sm}^{3+}$ doping due to concentration quenching.

In the opposite, a strong decrease of the fluorescence intensity was found in all opaque glass ceramic samples which had only a small glass phase and a lot of large crystals. In these cases, it is not possible to excite the $\mathrm{Sm}^{3+}$ ions in the glassy volume, and additionally, concentration quenching exists.

Thermal treatment was carried out with all undoped and doped glass samples to study the crystallization behavior. Exothermic peaks were detected in the DTA curves around 950, 1050 and $1120^{\circ} \mathrm{C}$. At first, all samples were treated for 3 hours at these temperatures, and the crystal phases formed were analyzed with different methods. The main crystal phase was $\mathrm{Zn}_{2} \mathrm{SiO}_{4}$ (willemite and other modifications) with a needle-like form and strong birefringence. With increasing temperature of thermal treatment, and increasing $\mathrm{Al}_{2} \mathrm{O}_{3}$ content additionally $\mathrm{ZnAl}_{2} \mathrm{O}_{4}$ (gahnite) and high quartz mixed crystals were found (Fig. 5). The crystallization tendency increases with the $\mathrm{ZnO}$ and $\mathrm{Al}_{2} \mathrm{O}_{3}$ content. The $\mathrm{Sm}^{3+}$-ions are accumulated in the glassy phase. It was not possible to detect samarium in the $\mathrm{SiO}_{2}$-droplet phase of glass samples with phase separation or in the various crystal phases. The $\mathrm{Sm}^{3+}$ ion (radius $\left.\sim 1.0 \AA\right)$ is in comparison with $\mathrm{Mn}^{2+}(\mathrm{r} \sim 0.66 \AA)$ too large for incorporation in the $\mathrm{Zn}_{2} \mathrm{SiO}_{4}, \mathrm{ZnAl}_{2} \mathrm{O}_{4}$ or $\mathrm{SiO}_{2}$ crystal phases with much smaller ionic radii $\left(\mathrm{Zn}^{2+}: \mathrm{r} \sim 0.60 \AA \mathrm{CN} 4\right.$ and $0.74 \AA$ at $\mathrm{CN} 6 ; \mathrm{Al}^{3+}: 0.39 \AA$ at $\mathrm{CN} 4$ and $0.54 \AA$ at $\mathrm{CN} 6$ ) [7]. 


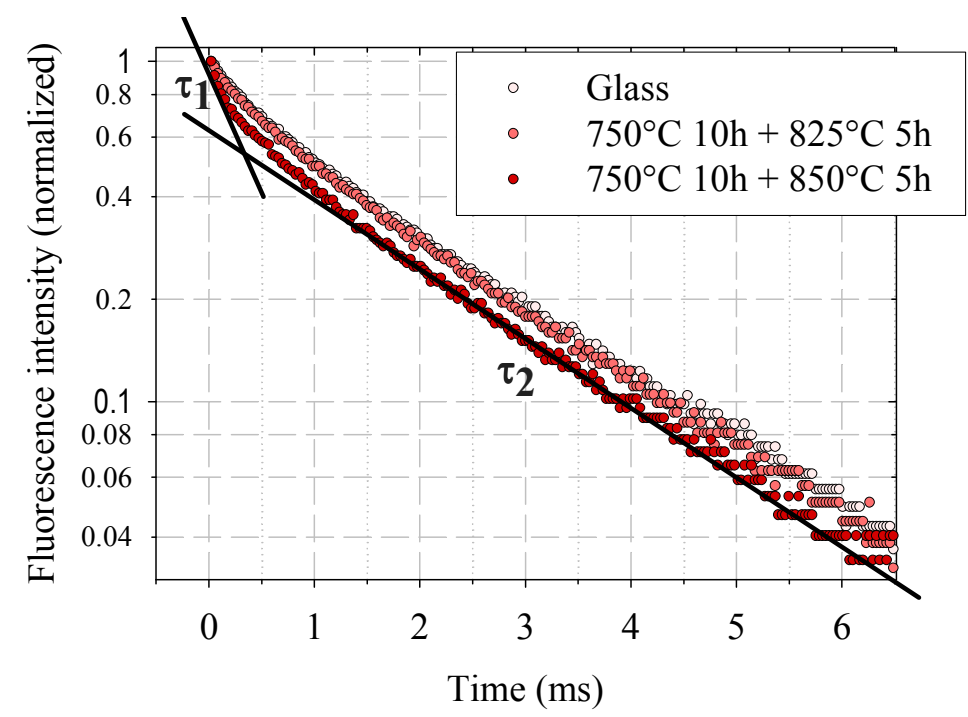

Fig. 4: Fluorescence decay curves of glass and ceramic samples, ZAS5B/10 20 $\mathrm{Sm}^{3+}$ per $\mathrm{cm}^{3}$ with fitted lifetimes.

The fluorescence decay $\left(\log \mathrm{I}_{\mathrm{F}}\right)$ behavior is not single exponentially with time. Two different lifetimes, $\tau_{1} \sim 0.5 \mathrm{~ms}$ and $\tau_{2} \sim 2.2 \mathrm{~ms}$, can be fitted. The origin could be two different local structures of the $\mathrm{Sm}^{3+}$ ions.

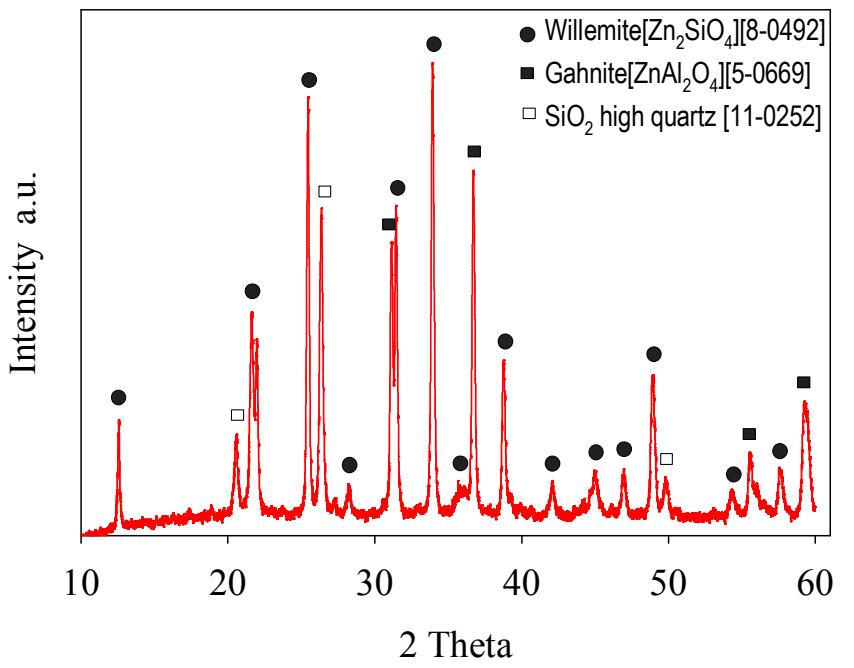

Fig. 5: XRD pattern of glass sample ZAS1 with $10^{20} \mathrm{Sm}^{3+}$ per $\mathrm{cm}^{3}$ after thermal treatment: 3 hours at $1120^{\circ} \mathrm{C}$.

The sample is nearly completely crystallized. The SEM and TEM images of the same samples are demonstrated at Figs. $6 \mathrm{~b}$ and c.

EDX analyses have shown that the white crystals are $\mathrm{Zn}_{2} \mathrm{SiO}_{4}$ (Fig. 6b), and the small cubic crystals mainly $\mathrm{ZnAl}_{2} \mathrm{O}_{4}$, but $\mathrm{SiO}_{2}$ mixed crystals could not be excluded too (Fig. 6c). The glassy phase between the crystals is only very small. The $\mathrm{Sm}^{3+}$ fluorescence of these strongly crystallized samples is only very low.

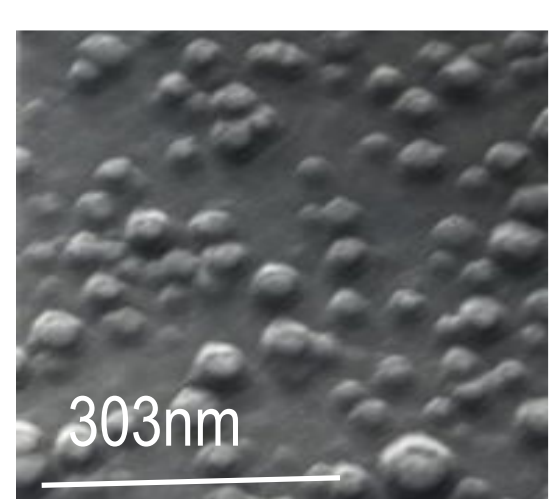

a)

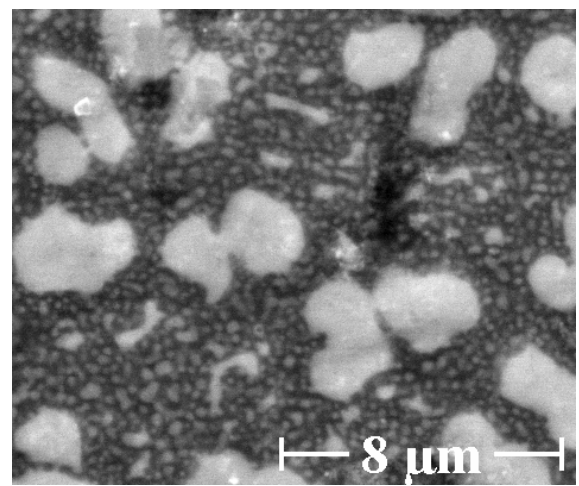

b)



c)

Fig. 6: TEM and SEM micrographs of ZAS1/10 ${ }^{20} \mathrm{Sm}^{3+} \mathrm{cm}^{-3}$ samples

a) After normal cooling: phase separation with $\mathrm{SiO}_{2}$ rich droplets

b) and c): Quenched samples after thermal treatment at $1120^{\circ} \mathrm{C}$ for 3 hours.

It is known that ions with $\mathrm{d}^{10}$ electronic configuration like $\mathrm{Zn}^{2+}, \mathrm{Cu}^{+}, \mathrm{Ag}^{+}$, etc. show an intense and broad absorption band in the ultraviolet region which can also show luminescence [4]. In this work, all undoped glasses, which had very high UV transmission, $<250 \mathrm{~nm}$, and the prepared glass ceramics were measured by luminescence excitation and emission spectroscopy. Typical spectra are given in Fig. 7. All samples have shown blue luminescence emission with excitation in the UV 
around $250 \mathrm{~nm}$. Significant differences were found between glasses and glass ceramics with the same composition. The glass samples provide broad emission with maxima around 370 and 485 $\mathrm{nm}$. The glass ceramic samples show much higher blue emission with a maximum at $370 \mathrm{~nm}$.

The $\mathrm{Zn}^{2+}$ ions are fourfold coordinated in $\mathrm{Zn}_{2} \mathrm{SiO}_{4}$ and in $\mathrm{ZnAl}_{2} \mathrm{O}_{4}$. It could be assumed that the emission at $370 \mathrm{~nm}$ is due to electronic transitions in fourfold coordinated $\mathrm{Zn}^{2+}$ in the glass ceramics and emission maximum at $485 \mathrm{~nm}$ of the glass samples is causes by six fold coordinated $\mathrm{Zn}^{2+}$ ions. The emission maximum at $370 \mathrm{~nm}$ is much lower. That would mean that $\mathrm{Zn}^{2+}$ ions can be coordinated with 4 to 6 oxygens in the glasses and act as both network former and modifier.

So, it is possible to obtain stable glass formation in this ternary system up to high $\mathrm{ZnO}$ and low $\mathrm{SiO}_{2}$ content. Glasses and glass ceramics have shown also blue luminescence emission by UV lamp excitation with the Hg-line at $254 \mathrm{~nm}$. Strong afterglow could be observed with the glass ceramic samples. The nature of this effect is not clear.



Fig. 7: Luminescence excitation and emission spectra of undoped glass and glass ceramic samples, demonstrated with samples ZAS4 (40ZnO- $\left.10 \mathrm{Al}_{2} \mathrm{O}_{3}-50 \mathrm{SiO}_{2}\right)$ as glass and glass ceramic with $\mathrm{Zn}_{2} \mathrm{SiO}_{4}$ crystal phase.

\section{Summary}

Stable glasses in the composition range in mol\% 35-50 $\mathrm{ZnO}-10-15 \mathrm{Al}_{2} \mathrm{O}_{3}-40-55 \mathrm{SiO}_{2}$ were prepared, undoped and doped with $1 \times 10^{19}$ and $1 \times 10^{20} \mathrm{Sm}^{3+}$ per $\mathrm{cm}^{3}$ glass as luminescent species for the visible region, especially for blue (undoped) and orange-red (with $\mathrm{Sm}^{3+}$ ) emission.

Phase separation occurs in glass samples with high $\mathrm{SiO}_{2}$ content. $\mathrm{SiO}_{2}$-rich droplets in a $\mathrm{Zn}^{2+}-\mathrm{Al}^{3+}$ enriched matrix were formed. $\mathrm{Sm}^{3+}$ ions prefer accumulation in the $\mathrm{Zn}^{2+}-\mathrm{Al}^{3+}$-rich glass matrix.

By thermal treatment glass samples were transformed into glass ceramics with the main crystal phases: $\mathrm{Zn}_{2} \mathrm{SiO}_{4}$ (willemite), $\mathrm{ZnAl}_{2} \mathrm{O}_{4}$ (gahnite) and $\mathrm{SiO}_{2}$-mixed crystals. XRD, SEM and TEM measurements were carried out. The luminescent $\mathrm{Sm}^{3+}$ ions are concentrated in the glass matrix. The glasses and glass ceramics have interesting chemical and physical properties, high $\mathrm{Tg}$ around $700^{\circ} \mathrm{C}$, low thermal expansion coefficient, TEC $<4 \mathrm{ppm} / \mathrm{K}$, and high chemical stability.

The refractive indices, $\mathrm{n}_{\mathrm{e}}$, increase with increasing $\mathrm{ZnO}$ content from 1.61 to 1.67 , and decrease with increasing $\mathrm{Al}_{2} \mathrm{O}_{3}$ content. The changes in the Abbe number are only small, $v_{\mathrm{e}} \sim 49 \pm 2$. 
The undoped glass samples with high purity have very high UV transmission, edge $<250 \mathrm{~nm}$, and provide blue emission with a maximum at $485 \mathrm{~nm}$ by UV excitation due to electron transitions of $\mathrm{Zn}^{2+}$ with $\mathrm{d}^{10}$ configuration. It is assumed that the $\mathrm{Zn}^{2+}$ ions are six fold and fourfold coordinated with oxygen in these glasses.

The undoped glass ceramic samples show much higher blue emission with a maximum at $370 \mathrm{~nm}$ due to fourfold coordination with oxygen in the crystal phases $\mathrm{Zn}_{2} \mathrm{SiO}_{4}$ (willemite) and $\mathrm{ZnAl}_{2} \mathrm{O}_{4}$ (gahnite).

The $\mathrm{Sm}^{3+}$ ions could neither be accumulated in the crystal phases nor in the $\mathrm{SiO}_{2}$ droplets of phase separated glasses. They are too large. They prefer the Zn-Al-rich glass phases.

A large fluorescence amplification effect could be obtained with low $\mathrm{Sm}^{3+}$-doping by phase separation of glass samples, or formation of translucent glass ceramics. The origin of this unusual increase of the fluorescence intensity is of complex nature. Main reasons should be the increase of $\mathrm{Sm}^{3+}$ content in the matrix phase and scattering effects.

\section{References}

[1] H. T. Vu, A. Herrmann, G. Völksch, D. Ehrt, $8^{\text {th }}$ Int. Otto Schott Colloq., Jena, 2006, Proc. p. 47

[2] E. Tkalcec, S. Kurajica, H. Ivankovic: J. Non-Cryst. Sol. 351 (2005) 149-157

[3] T. Suzuki, K. Horibuchi, Y. Ohishi: J. Non-Cryst. Sol. 351 (2005) 2304-2309

[4] G. Blasse, B.C. Grabmeier: Luminescent Materials, Springer, Berlin 1994

[5] A. Herrmann, D. Ehrt: J. Non-Cryst. Sol. 354 (2008) 916-926

[6] E. N. Bunting: J. Res. Nat. Bur. Stand. 4 (1930) 131-136

[7] R. D. Shannon: Acta Cryst. A32 (1976) 751 